\title{
Farklı Ekmek Çeşitlerinin Karbonhidrat İntoleransı Olmayan Kilolu ve Obez Gönüllüllerde Etkisi
}

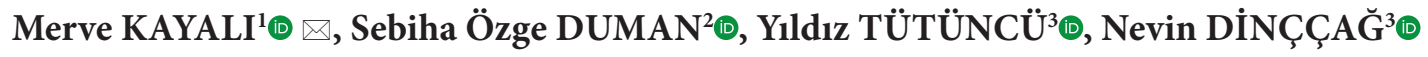 \\ ${ }^{1}$ İETT İşletmeleri Genel Müdürlüğü, İş Sağlığı ve Güvenliği Müdürlüğü, İstanbul \\ ${ }^{2}$ İstanbul Üniversitesi, Onkoloji Enstitüsü, İstanbul \\ ${ }^{3}$ İstanbul Üniversitesi, İstanbul Tip Fakültesi, İç Hastalıkları Anabilim Dalı, Endokrinoloji ve Metabolizma Hastalıkları Bilim Dalı, İstanbul \\ Bu makaleye yapılacak atıf: Kayalı M, Duman SÖ, Tütüncü Y, Dinççağ N. Farklı Ekmek Çeșitlerinin Karbonhidrat İntoleransı Olmayan Kilolu ve Obez Gönüllülerde Etkisi. \\ Türk Diyab Obez 2019;1: 1-13.
}

\begin{abstract}
ÖZET
Amaç: Ülkemizde farklı ekmek çeşitlerinin ve tam buğday unlu gıdaların üretimi son yıllarda artmış olsa da hâlâ çok yüksek oranda beyaz ekmek tüketilmektedir. Çalışmada farklı ekmek çeşitleri tüketiminin obez ve kilolu bireylerde glukoz, insülin ve GLP-1 yanıtları üzerine etkilerinin araştırılması amaçlandı.

Gereç ve Yöntemler: Çalı̧̧mamıza yaşları $28-50$ yıl ve Beden Kütle İndeksi (BKİ) $25-35$ kg/m² aralığında; 75 gram glukozlu Oral Glukoz Tolerans Testi (OGTT) ile karbonhidrat metabolizmasının normal olduğu saptanmış 21 gönüllü [10 kilolu (BKİ: $25-30 \mathrm{~kg} / \mathrm{m}^{2}$ ve 11 obez (BKİ: 30-35 kg/m²)] birey dahil edildi. Gönüllülere sabah kahvaltıda yalnızca $250 \mathrm{ml}$ su ile 50 gram karbonhidrat $(\mathrm{KH})$ içeren test ekmekleri; 102 gramlık beyaz ekmek ve 114 gramlık tam buğday ekmeği; birer hafta ara ile yedirildi. Testin başlangıcında ve ekmek tüketiminin başlangıcından itibaren 60, 120 ve 180. dakikalarda glukoz, insülin ve Glukagon benzeri Peptid-1 (GLP-1) düzeylerini belirlemek üzere venöz kan örnekleri alındı. Test ekmeklerinin glukoz, insülin ve GLP-1 düzeylerini yükseltme hızları; eğri altında kalan alanları (AUC) hesaplanarak belirlendi.

Bulgular: Tüm bireylerde beyaz ekmeğin, daha hızlı emilime yol açarak postprandiyal glukoz değerlerini yükselttiği, insulin ve GLP-1 düzeylerini artırdığı görüldü $(\mathrm{p}<0,05)$. Kilolu bireylerde beyaz ekmekle yapılan uygulamada 1. st (postabsorptif) ve 2. st (postprandiyal) fazlarda glukoz, insulin cevaplarında anlamlı olmayan, GLP-1 düzeyinde 120. dakikada anlamlı düzeyde $(\mathrm{p}<0,05)$ artış saptandı. Obez bireylerin her iki test ekmeği uygulamasında da glukozun tüm tokluk fazlarında, insülinin ise 60. dakika toklukta hızlı yükseldiği $(\mathrm{p}<0,01)$ saptand1; GLP-1 düzeyinde anlamlı değişiklik görülmedi.

Sonuç: Çalışmamız, beyaz ekmeğin karbonhidrat metabolizmasındaki olumsuz etkilerini işaret etmektedir. Toplumdaki tüm bireylere, özellikle obezlere, gelecekte maruz kalacakları metabolik hastalıkları önlemek için beyaz ekmek yerine tam tahıl ekmeği önerilmeli ve tam tahıl ekmek tüketimi yaygınlaştırılmalıdır.
\end{abstract}

Anahtar Sözcükler: GLP-1, Ekmek tüketimi, İnkretin, Karbonhidrat

\section{The Effect of Different Bread Varieties on Non-Carbonhydrate Intolerance with Owerweight and Obes Volunteers}

\begin{abstract}
Aim: Although the consumption of different bread types and whole wheat flour foods has recently increased in our country, the consumption of white bread is still very high. In our study we aimed to investigate the effects of consumption of different bread types on glucose, insulin and GLP-1 responses in obese and overweight individuals.

Material and Methods: A total of 21 volunteers with Body Mass Index (BMI) $25-35 \mathrm{~kg} / \mathrm{m}^{2}$ (10 overweight and 11 obese) and aged 2850 years, and have carbohydrate tolerance after normal 75 grams glucose Oral Glucose Tolerance Test (OGTT), were allocated for this
\end{abstract}

ORCID: Merve Kayalı / 0000-0001-8795-5130, Sebiha Özge Duman / 0000-0003-3986-4546, Yıldız Tütüncü / 0000-0001-6764-1994, Nevin Dinççağ / 0000-0002-3905-6429 
study. The volunteers were given two test breads in one week intervals, as white bread or whole wheat bread after consumption of the test breads, At the beginning and after consumption of breads at $60^{\text {nd }}, 120^{\text {th }}$ and $180^{\text {nd }}$ minutes, blood samples were taken to to investigate glucose, insulin and glucagon-like peptide-1 (GLP-1) levels. The rate of increase of glucose, insulin and GLP-1 levels during test were calculated using the areas under the curve (AUC).

Results: It was we observed that postprandial glucose and insulin levels were increased after consumption of white bread in individuals $(\mathrm{p}<0.05)$.In overweight individuals, while both glucose levels and insulin response showed no significant increase to the white bread test in the post-absorptive and postprandial phase, the GLP-1 levels showed a significant increase in the 120th minute $(\mathrm{p}<0.05)$. In obese individuals, while glucose levels showed a significant response in all postprandial phases to both test breads and insulin showed a fast increase in the 60nd postprandial mark ( $\mathrm{p}<0.01$ ), there was no significant change in the GLP-1 levels.

Conclusion: Our study shows that white bread has a negative effect on carbohydrate metabolism. In order to prevent metabolic diseases in a society, whole wheat bread consumption should be increased and preferred over white bread, particularly in obese individuals.

Key Words: GLP-1, Bread consumption, Incretin, Carbohydrate

\section{GİRIŞ ve AMAÇ}

Ekmek, beslenmede önemli karbonhidrat kaynaklarındandır (1). Ülkemizde son zamanlarda farklı ekmek çeşitlerinin ve tam buğday unlu gidaların üretimi artmış olsa da birçok nedenle hâlâ yaygın kullanılan beyaz ekmek tüketimi daha fazladır (2). Epidemiyolojik çalışmalar tam buğday ekmeği tüketimi ile Tip 2 Diabetes Mellitus (T2DM) ve kardiyovasküler hastalık görülme sıklığının ters ilişkili olduğunu göstermiştir (3). Bazı klinik çalışmalar tam buğday ekmeği tüketiminin glisemik kontrolü iyileştirerek postprandiyal glukoz, insülin ve inkretin hormon yantları üzerine olumlu etkileri olduğunu göstermiştir $(4,5)$.

Tahıl ürünleri içeren kompleks karbonhidrat ürünlerinde diyet posası oranı yüksektir. Diyet posasının da kalp hastalıkları (6), hipertansiyon (7), kolon kanseri (8), T2DM (9) ve obezite (10) gibi birçok sağlık sorunlarında olumlu etkileri olduğu bilinmektedir. Alınması gereken ortalama posa miktarı $25 \mathrm{~g} /$ gün olarak belirlenmiştir. Ancak ülkemizde bu oran, beyaz ekmek tüketiminin yaygın olması nedeniyle çok düşüktür. Halbuki beyaz ekmeği tam buğday ekmeği ile değiştirerek diyet posasını artırmak mümkündür ve sıklıkla önerilen ve uygulanan bir yoldur (11). Tam buğday ekmeğinin içindeki posa nedeniyle karbonhidratın parçalanmasını yavaşlatarak, emilim hızını düşürdüğü, böylelikle postprandiyal glukoz düzeyini azalttığı ve insülin metabolizmasını iyileştirdiği gösterilmiştir (12).

Glukoz homeostazisi, insülin ve insülin karşıtı hormonlar üzerinden düzenlenmekle birlikte, regulasyonla yakından ilişkili olduğu gösterilen diğer faktörler bağırsak kökenli hormonlar olup; başlıcaları Glukoz bağımlı Insulinotropik Polipeptid (GIP) ve Glukagon-like Peptide-1 (GLP-1) gibi inkretin hormonlardır (13). İnkretin hormonlarm postprandiyal insülin salınımının \%60'indan sorumlu olduğu ve pankreas $\beta$-hücre fonksiyonunun korunmasında önemli rolleri olduğu bilinmektedir $(14,15)$. Oral yolla alınan glukozun indüklediği, insülin sekresyonuna etkili olan inkretin hormonlardan majör olanı GLP1'dir. Glukoza bağımlı olarak $\beta$-hücrelerinde insülin sekresyonunu artırır ve pankreas $\alpha$-hücrelerinde glukagonu baskılayarak karaciğerden glukoz çıkışını baskılar; böylelikle tokluk kan şekerini düşürür ve periferik hücrelerdeki glukolipotoksisiteyi önler (16-18). İnsülin sekresyonuna majör etkili olan GLP-1, pankreas adacık hücrelerinde somatostatin sekresyonunu da artırdığı bilinmektedir (19).

İnkretin hormonun sekresyonu için en önemli uyaran sindirim sisteminde karbonhidrat bulunması gerekliliğidir (20). Ancak sekresyon yanıtındaki büyüklüğün belirleyicisi karbonhidrat türüdür (21). Besinlerdeki yağ (22) ve proteinler de GLP-1 sekresyon düzeyinde etkilidir ama esas etkili olan karbonhidratlardır (23-25). İnsanda GLP1, ileumdan gida alımından sonra erken (30-45 dk sonra) ve geç (60-90 dk sonra) olmak üzere salgılanır. Tokluktaki salınımı, açlıktaki miktarından 5-10 kat fazladır (26). Ancak farklı tip karbonhidratların tüketiminin inkretin yanıtları üzerine etkileri hâlâ tam olarak bilinmemektedir (27).

\section{GEREÇ ve YÖNTEMLER}

Çalışmamız açı etiketli, randomize, çapraz kontrollü bir çalışmadır. Helsinki Deklarasyonu çerçevesinde gerekli izinler ile katılımcıların yazılı ve sözlü onamı alınarak yapılmıştır.

İETT İşletmeleri Genel Müdürlüğü İş Sağllğı ve Güvenliği Müdürlüğü Polikliniğine sağlık kontrolü amacıyla başvuran, yaşları 28-50 yıl ve BKİ $25-35 \mathrm{~kg} / \mathrm{m}^{2}$ aralığında olan sağlıklı kişilere 75 gram glukoz ile Oral Glukoz Tolerans Testi (OGTT) uyguland. American Diabetes Association (ADA) ve Türkiye Endokrin ve Metabolizma Derneği (TEMD) kılavuzları tanı kriterleri esas alınarak karbonhidrat intoleransı saptanmayan; başka bir deyişle karbonhidrat metabolizması normal olan (açlık glukozu<100 mg/dl; 2 . saat postprandiyal glukozu $<140 \mathrm{mg} / \mathrm{dl}), 21$ gönüllü $[10$ 
kilolu (BKİ $25-30 \mathrm{~kg} / \mathrm{m}^{2}$ ) ve 11 obez birey (BKİ $30-35 \mathrm{~kg} /$ $\left.\mathrm{m}^{2}\right)$ ] çalışmaya dahil edildi.

Katılımcıların sigara-alkol kullanımı, başka bir kronik hastalık, gluten enteropatisi ya da endokrinopati varlığı, ilaç kullanımı olup olmadığı sorgulandı. Sigara içen, alkol kullanan, kronik hastalığı olan, ilaç (antihipertansif, antilipidemik, antidepresan gibi) ya da gida destek ürünü kullanan ve profesyonel anlamda sporcu olan ya da aşırı fiziksel aktivite yapan bireyler çalışmadan dışlandı.

Bireylerin detaylı anamnezleri, fizik muayene bulguları, antropometrik ölçümleri [bel çevresi $(\mathrm{cm})$, kalça çevresi $(\mathrm{cm})$, biyoempedans cihazı ile vücut kompozisyonları bileşimi] kaydedildi. Biyokimyasal parametreleri için kan örnekleri alındı. İnsülin direnci varlığ 1 Homeostasis Model of Assesment indeksi (HOMA-IR = [Açlık insülini $(\mu \mathrm{U} / \mathrm{ml})$ xAçlık glukozu (mg/dl)]/405 formülü) ile hesaplandı.

BKİ düzeyine göre hafif şişman ve obez olarak gruplanan bireylerden 24 saatlik besin tüketimi istendi ve en az 1 hafta öncesinde başlamaları planlanarak standart bir beslenme programı (Diyette karbonhidrat \%50, Protein \%20 ve yağ \%30’u geçmeyecek şekilde) oluşturuldu. 24 saatlik besin tüketim formu verileri, Beslenme Bilgi Sistemi (BEBİS) gida programıyla değerlendirildi ve BEBİS ile bireylerin testten bir gün önceki aldıkları gıdaların enerji, makro besin ögeleri, posa ve kolesterol miktarları detaylı bir şekilde hesaplandı. Bireylerin çalışma sürecinde kafein, tıbbi ilaç ve herhangi bir besin destek ürünü tüketmemeleri ve ağır bir fiziksel aktivitede bulunmamaları istendi.

Bireylere birer hafta ara ile 2 farklı test ekmeği kahvaltıda yalnızca $250 \mathrm{ml}$ su ile verildi. Besin içerikleri Tablo l'de gösterilmiş olan test ekmekleri, 50 gram $\mathrm{KH}$ içeren 102 gramlık beyaz ekmek ve 114 gramlık tam buğday ekmeğidir.

Test günü sabah, 12 saat açlık sonrası polikliniğe davet edilen katılımcılar test ekmeğini yalnızca su içerek 15 dakika içinde yediler, ekmekle birlikte başka bir gıda maddesi verilmedi. Ekmek tüketiminin başlangıcında ve yemeye başladıklarından itibaren 60, 120 ve 180 . dakikalarda glukoz, insülin ve GLP-1 düzeylerini belirlemek üzere venöz kan

Tablo 1: 50 gram KH içeren test örneklerinin besin içerikleri.

\begin{tabular}{lcc}
\hline İcerik & Beyaz ekmek & Tam buğday ekmeği \\
\hline Ekmek Miktarı (g) & 102 & 114 \\
\hline KH Miktarı (g) & 50 & 50 \\
\hline Enerji (kcal) & 258 & 267 \\
\hline Diyet Lifi (g) & 5,61 & 8,68 \\
\hline Yağ (g) & 1,53 & 1,61 \\
\hline Protein (g) & 8,07 & 8,51 \\
\hline
\end{tabular}

örnekleri alındı. Uygulama, aynı bireye 1 hafta sonra diğer test ekmeği ile aynen tekrarlandı. Uygulamanın ilk haftası bireylere tam buğday ekmeği (114 g) ve sonraki hafta beyaz ekmek (102 g) verilerek çalışma tamamlandı.

Kan örnekleri, vacutainer ile antecubital venden alındı, GLP-1 hariç tüm biyokimyasal parametreler için hemen çalışmanın gerçekleştirildiği ünitenin lokal laboratuvarına yönlendirilerek tetkik edildi, sonuçlara aynı gün ulaşıldı. GLP-1 incelenmesi, İstanbul Üniversitesi İstanbul Tip Fakültesi Merkez Biyokimya Laboratuvarı'nda çalıșma tamamlandıktan sonra eș zamanlı olarak gerçekleștirileceğinden; serum ve plazma örnekleri test çalışılana kadar $-80^{\circ} \mathrm{C}$ 'de saklanmak üzere EDTA'lı ve kuru tüplere alındı.

GLP-1 kitinin değerlendirilmesi için hazır kaplanmış ELISA plağı kullanıldı. ELISA kiti (SunRed Biothecnology Company ELISA kiti) en yüksek ölçülebilen düzeylerinde yani 0,6 pmol/L-180 pmol/L arasında idi. Ölçümden önce $-80^{\circ} \mathrm{C}$ 'deki serum örneklerinin oda sıcaklığına gelmesi sağlandi. Her bir serum örneği sulandırılmadan $40 \mu \mathrm{l}$ miktarında kuyucuklara konuldu. GLP-1'e özgü biyotinlenmiş $10 \mu \mathrm{l}$ anti-glukagon-like peptide-1 antikoru ve $50 \mu \mathrm{l}$ streptavidin-HRP eklendi. Bir kompetitif serin proteaz inhibitörü olan Aprotinin eklenmesi sayesinde enzimlerin aktif bölgeleri bloke edilerek, kan örneklerindeki GLP-1'in stabilizasyonu sağlanmış oldu. Daha sonra 1 saat süreyle $37^{\circ} \mathrm{C}$ 'de inkübe edildi, ardından yıkama işlemleri gerçekleştirildi. Her kuyucuğa $50 \mu \mathrm{l}$ Kromojen A ve $50 \mu \mathrm{l}$ Kromojen B eklenmesinden sonra plak 10 dakika karanlıkta inkübasyona bırakıldı. Stop solüsyonun eklenmesinin ardından plağın absorbansı $450 \mathrm{~nm}$ dalga boyunda ölçüldü.

Verilerin tanımlayıcı istatistiklerinde ortalama, standart sapma, en düşük, en yüksek, frekans ve oran değerleri kullanılmıştır. Analizlerde SPSS 22.0 programı kullanılmıștır.

Açlik ve postprandiyal glukoz, insülin ve GLP-1'in zamana bağlı değişimleri grafiğindeki, eğri altında kalan alan (Area Under the Curve, AUC) yüz ölçümü hesaplaması, trapezoidal metod kullanılarak hesaplandı (GraphPad Prism 6.07).

Bu çalışma İstanbul Üniversitesi Bilimsel Araştırma Projeleri Birimi tarafından desteklenmiştir (Proje No: 46203).

\section{BULGULAR}

Çalışmaya katılan 6'sı kadın, 15’i erkek olan katılımcıların yaş ortalaması $37,6 \pm 6,4$ yıl idi. Vücut ağırlığ 1 ortalaması $88,1 \pm 14,3 \mathrm{~kg}$, bel çevresi ortalamasi $102,5 \pm 10,8 \mathrm{~cm}$, kalça

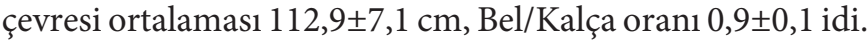
Bireylerin demografik özellikleri Tablo 2'de özetlenmiştir. 
Tablo 2: Tüm bireylerin demografik özellikleri.

\begin{tabular}{lccc}
\hline Özellikler & Ortalama \pm SS $^{*}$ & Minimum & Maksimum \\
\hline Yaş $(\mathrm{yll})$ & $37,6 \pm 6,4$ & 28,0 & 49,0 \\
\hline Boy $(\mathrm{cm})$ & $170,0 \pm 98$ & 151,0 & 185,0 \\
\hline Vücut ağırlı̆̆ı $(\mathrm{kg})$ & $88,1 \pm 14,3$ & 61,2 & 109,3 \\
\hline BKİ $\left(\mathrm{kg} / \mathrm{m}^{2}\right)$ & $30,2 \pm 3,0$ & 26,2 & 35,0 \\
\hline Bel çevresi $(\mathrm{cm})$ & $102,5 \pm 10,8$ & 80,0 & 119,0 \\
\hline Kalça çevresi $(\mathrm{cm})$ & $112,9 \pm 7,1$ & 100,0 & 127,0 \\
\hline Bel/kalça oranı & $0,9 \pm 0,1$ & 0,7 & 1,0 \\
\hline Abdominal yağ $(\mathrm{kg})$ & $14,4 \pm 4,2$ & 7,0 & 20,9 \\
\hline Total yağ $(\mathrm{kg})$ & $29,1 \pm 7,0$ & 15,2 & 45,4 \\
\hline Sistolik Kan Basıncı $(\mathrm{mmHg})$ & $116,0 \pm 6,5$ & 104,0 & 134,0 \\
\hline Diyastolik Kan Basıncı $(\mathrm{mmHg})$ & $79,9 \pm 6,1$ & 64,0 & 93,0 \\
\hline
\end{tabular}

${ }^{\star}$ Standart Sapma.

Tablo 3: Tüm bireylerde insülin direnci varlığı ve ailede DM öyküsü.

\begin{tabular}{lccc}
\hline & & Sayı & Yüzde (\%) \\
\hline Ailede DM öyküsü & Var & 8 & 38,1 \\
\hline & Yok & 13 & 61,9 \\
\hline İnsülin Direnci & ${ }^{\star}$ Var & 6 & 28,6 \\
\hline & ${ }^{*}$ Yok & 15 & 71,4 \\
\hline
\end{tabular}

+ [HOMA: açlık insülini $(\mu \mathrm{u} / \mathrm{ml})$ xaçlık plazma glukozu $(\mathrm{mg} / \mathrm{dl}) / 405]$.

*Var HOMA-IR $>2.5 \quad$ ** Yok:HOMA-IR<2.5

Katılımcıların tümü değerlendirildiğinde $\% 38$,1'inde ailede DM öyküsü varken \%61,9'unda ailelerinde diyabetli olmadığı görüldü. İnsülin Direncini işaret eden göstergelerden biri olarak kabul edilen Bel Çevresi ölçümü, tüm bireylerde ortalama $102,5 \pm 10,8 \mathrm{~cm}$ değeri ile ülke ortalamasının üstünde saptandi. Insülin direncinin objektif başka bir göstergesi HOMA-IR dir. HOMA-IR kesim noktası 2.5 olarak kabul edildiğinde katılımcıların \%28,6'sında insulin direncinin mevcut olduğu görüldü (Tablo 3).

Test ekmekleri (beyaz ve tam buğday ekmeği) ile yapılan uygulamalarda test ekmeğine cevaben gelişen tokluk glukoz, insülin ve GLP-1 düzeyleri Tablo 4 de, değişim farkları Şekil 1,2 ve 3'de gösterilmiştir.

Beyaz ekmek ile yapılan uygulamada teste giriște bireylerin ortalama açlık glukoz değeri daha yüksek olmasına rağmen postprandiyal glukoz değerlerindeki artışın, tam buğday ekmek ile yapılan uygulamadaki değerlere göre anlamlı $(\mathrm{p}<0,05)$ olarak daha fazla olduğu gözlendi (Tablo 4).

Beyaz ekmek ve tam buğday ekmeği uygulamalarında 0.dak.-120.dak.-180.dak insülin değerlerinde anlamlı
Tablo 4: Test Ekmeklerinin postprandiyal glukoz, insülin ve GLP-1 yanitlar.

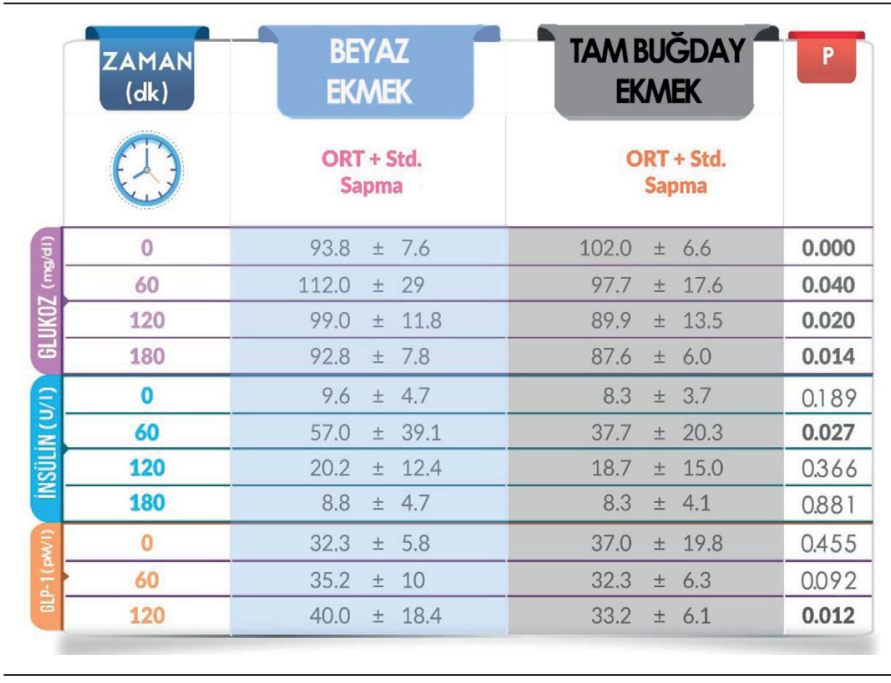

farklılık ( $>0,05)$ görülmemiş iken, beyaz ekmekli uygulamada 60. dakika postabsorbtif insülin değerinin, tam buğday ekmeğinin insulin artırıcı etkisine karşın, anlamlı $(\mathrm{p}<0,05)$ olarak daha yüksek olduğu saptandı (Tablo 4).

Beyaz ekmek ve tam buğday ekmeği uygulamalarında başlangıç ve postabsorbtif dönem (60. dakika) plazma GLP1 değerinde anlamlı farklılık ( $>0,05)$ görülmez iken, beyaz ekmekli uygulamada 120. dakika Plazma GLP-1 değeri, tam buğday ekmeğe göre anlamlı $(\mathrm{p}<0,05)$ olarak daha yüksek bulundu (Tablo 4).

Test ekmeklerinin glukoz, insulin ve GLP-1 değerlerini yükseltme hızları AUC değerleri Şekil 4,5,6'da gösterilmektedir. Beyaz ekmeğin daha hızlı emilime yol açarak glukozu 
yükselttiği, insulin sekresyonunu ivmeli artırdığı saptanırken, GLP-1 düzeylerini de artırdığı görüldü. Klinikte bazı bulguların değişim farkları ifade edilirken yüzölçümlerinin (AUC) hesabı yapıldığında daha değerli ve anlamlı bulgular ifade eder. Çalışmamızda parametrelerin değişim oranları şekil ile gösterilmiş, bunun yanısıra değişim farkının AUC ile de ifade edilmesi tercih edilmiştir.

Çalışmamızda bireyler BKİ esas alınarak kilolu ve obez olarak olarak değerlendirildi. BKİ $25-30 \mathrm{~kg} / \mathrm{m}^{2}$ arasında olan 10 ve $30-35 \mathrm{~kg} / \mathrm{m}^{2}$ arasında olan 11 kişi çalışmanın iki farklı grubunu oluşturdu. Her iki grubun demografik verileri ve biyokimyasal bulguları Tablo 5'de gösterilmiştir.
Kilolu ve obez bireylerin test ekmeklerine verdikleri tokluktaki glukoz, insülin ve GLP- 1 yanttları Tablo 6 ve Tablo 7'de gösterilmiştir.

Kilolu bireylerde beyaz ekmekle yapilan uygulamada 60 . dakika (postabsorbtif dönem) ve 120. dakikalarda (postprandiyal dönem) glukoz ve insülin cevaplarında anlamlı farklılıklar saptanmazken, GLP-1 düzeyi 120. dakikada anlamlı düzeyde $(\mathrm{p}<0,05)$ yüksek bulundu. Bu cevap, kilolu bireylerde glukoz homeostazisinin korunmasinda GLP-1'in etkili olduğunu düşündürmektedir ve çalışmamızda kilolu grupta GLP-1 düzeyinin yeterli olduğu ve yanıtının korunduğu olarak yorumlanabilir (Tablo 6).
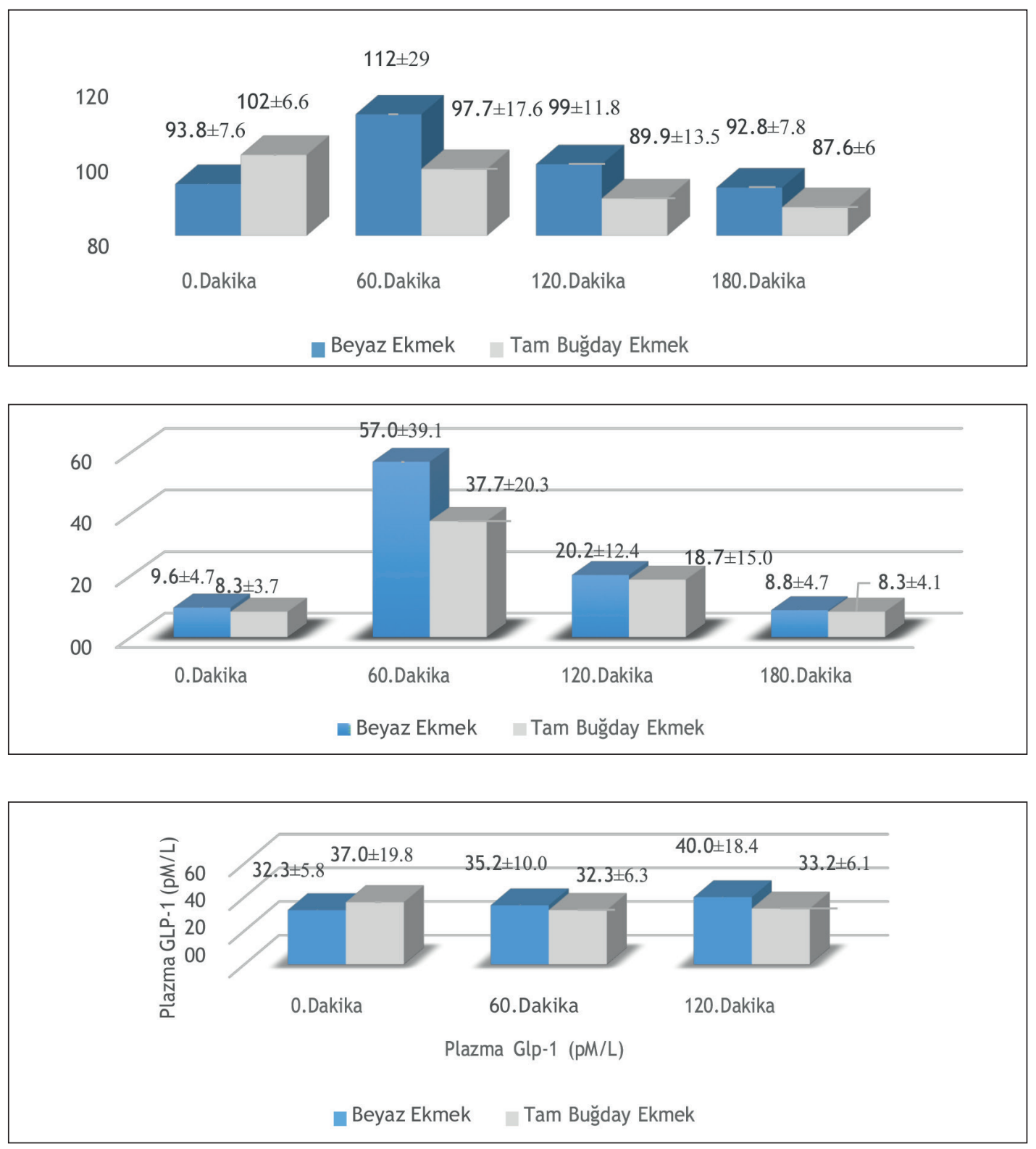

Şekil 1: Test ekmeklerinin zamana bağlı açlık ve postprandiyal ortalama glukoz değişimi.

Şekil 2: Test ekmeklerinin zamana bağlı açlık ve postprandiyal ortalama insülin değişimi.
Şekil 3: Test ekmeklerinin zamana bağlı açlık ve postprandiyal ortalama GLP-1 değişimi. 
Kilolu bireylerin glukoz, insulin ve GLP-1 düzeylerinin başlangıç ve başlangıca göre değişimleri Şekil 7, 8 ve 9'da; eğri altında kalan alanları da (AUC) Şekil 10, 11 ve 12'de gösterilmiştir.
AUC değerlendirilmesinde; kilolu bireylerde beyaz ekmek tüketiminin, glukoz değişimin altında kalan eğrisi (anlamlı olmayan), insulin ve GLP-1 değişim altındaki alanlar ise anlamlı $(\mathrm{p}<0,05)$ olarak yükssek bulundu.

Tablo 5: Kilolu ve obez bireylerdeki demografik ve laboratuvar verileri.

\begin{tabular}{lcc}
\hline & Kilolu $(\mathbf{n}=\mathbf{1 0})$ & Obez $(\mathbf{n}=\mathbf{1 1})$ \\
\hline Yaş (yıl) & $40,5 \pm 4,7$ & $34,9 \pm 6,9$ \\
\hline Kadın / Erkek (\%) & $40 / 60$ & $27,3 / 72,7$ \\
\hline Sistolik/ Diyastolik Arter Basıncı (mm/Hg) & $113,4 / 77,4$ & $118,5 / 82,1$ \\
\hline Vücut ağırlı̆̆ $(\mathrm{kg})$ & $77,5 \pm 11,5$ & $97,6 \pm 8,9$ \\
\hline BKİ (kg/m $\left.{ }^{2}\right)$ & $27,5 \pm 1,2$ & $32,7 \pm 1,6$ \\
\hline Bel çevresi (cm) & $95,9 \pm 9,0$ & $108,5 \pm 8,8$ \\
\hline Kalça çevresi (cm) & $108,2 \pm 5,3$ & $117,1 \pm 5,9$ \\
\hline Bel/Kalça Oranı & $0,9 \pm 0,1$ & $0,9 \pm 0,1$ \\
\hline Total yağ (kg) & $26,6 \pm 6,1$ & $31,4 \pm 7,3$ \\
\hline Abdominal yağ (kg) & $10,9 \pm 2,9$ & $17,5 \pm 2,3$ \\
\hline HOMA-IR & $1,9 \pm 0,8$ & $2,4 \pm 1,1$ \\
\hline Trigliserid (mg/dL) & $122,8 \pm 36,6$ & $99,4 \pm 45,3$ \\
\hline Total Kolesterol (mg/dL) & $225,5 \pm 46,1$ & $215,9 \pm 24,7$ \\
\hline HDL kolesterol (mg/dL) & $40,3 \pm 8,9$ & $35,4 \pm 5,3$ \\
\hline LDL kolesterol (mg/dL) & $160,6 \pm 39,5$ & $160,3 \pm 18,0$ \\
\hline Ürik asit (mg/dL) & $4,3 \pm 1,5$ & $4,7 \pm 1,3$ \\
\hline AST (U/L) & $21,2 \pm 3,2$ & $26,1 \pm 6,2$ \\
\hline ALT(U/L) & $27,0 \pm 8,8$ & $31,2 \pm 8,2$ \\
\hline TSH (uIU/mL) & $1,9 \pm 0,8$ & $1,7 \pm 0,9$ \\
\hline sT4 (ng/dL) & $0,9 \pm 0,1$ & $0,9 \pm 0,1$ \\
\hline
\end{tabular}

Tablo 6: Kilolu bireylerde beyaz ekmek ve tam buğday ekmek testlerinin açlik ve postprandiyal glukoz, insülin ve GLP-1 yanitları.

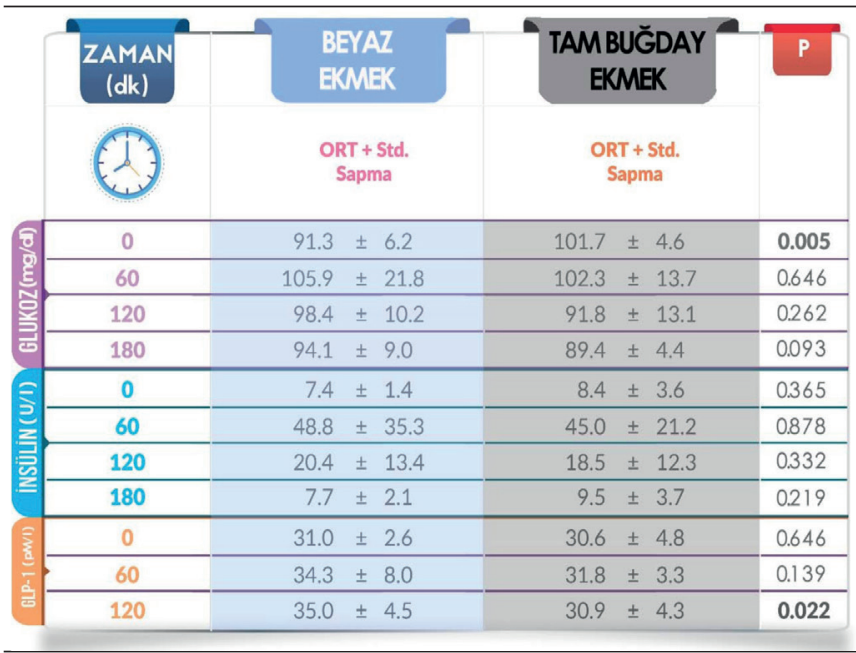

Tablo 7: Obez bireylerde beyaz ekmek ve tam buğday ekmek testlerinin açlık ve postprandiyal glukoz, insülin ve GLP-1 yanitları.

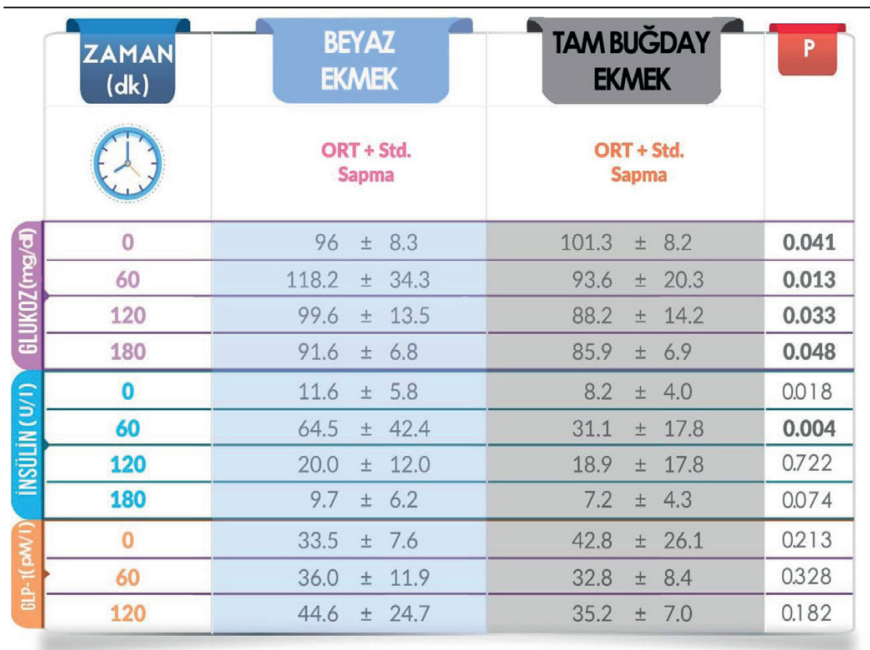



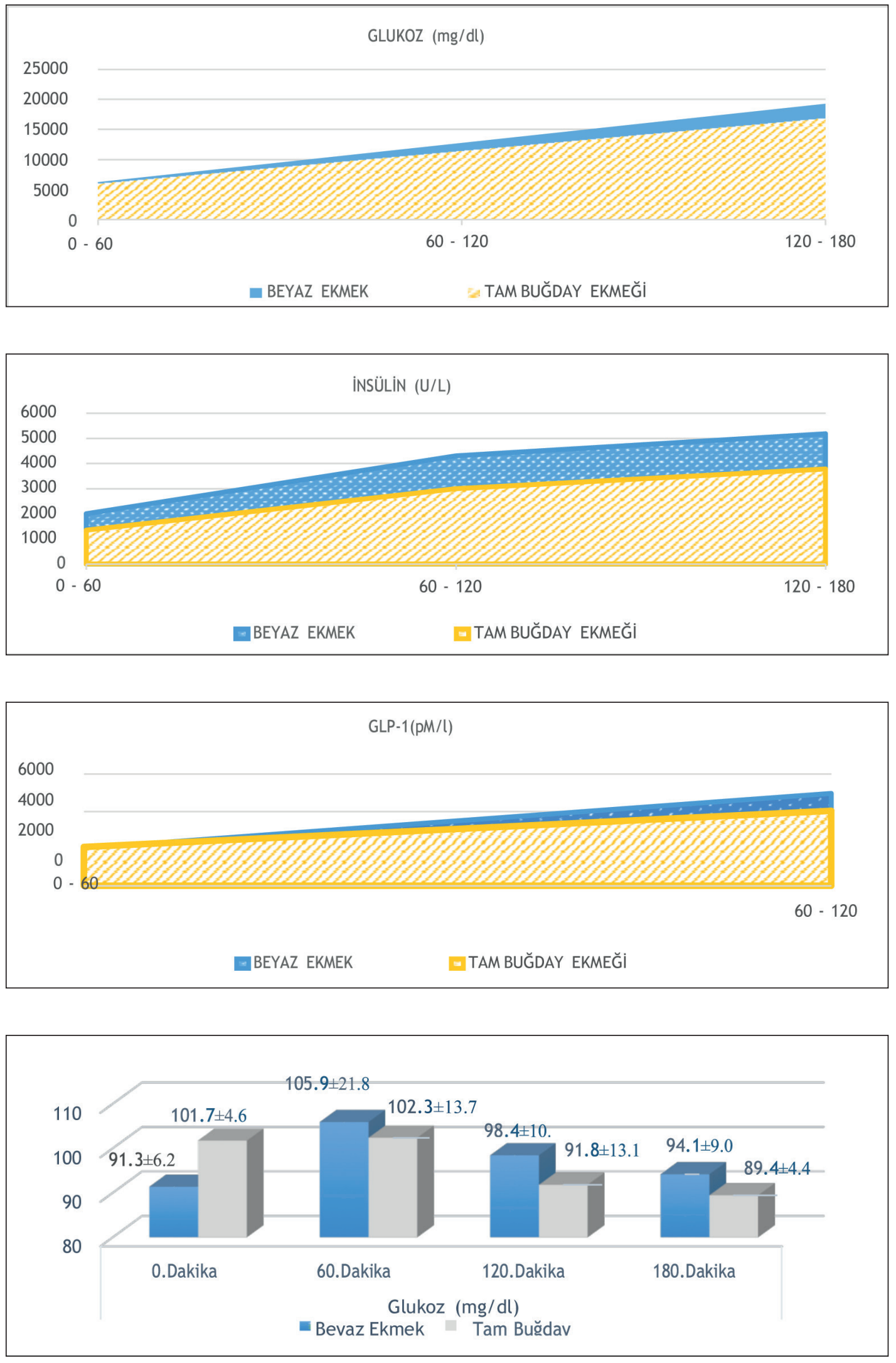

Şekil 4: Test ekmeklerinin postprandiyal glukoz değişimlerinin AUC değerleri.

Şekil 5: Test ekmeklerinin postprandiyal insülin değişimlerinin AUC değerleri.

Şekil 6: Test ekmeklerinin postprandiyal GLP-1 değişimlerinin AUC eğrileri.

Şekil 7: Kilolu bireylerde beyaz ekmek ve tam buğday ekmek testlerinin açlık ve postprandiyal glukoz yanıtları. 

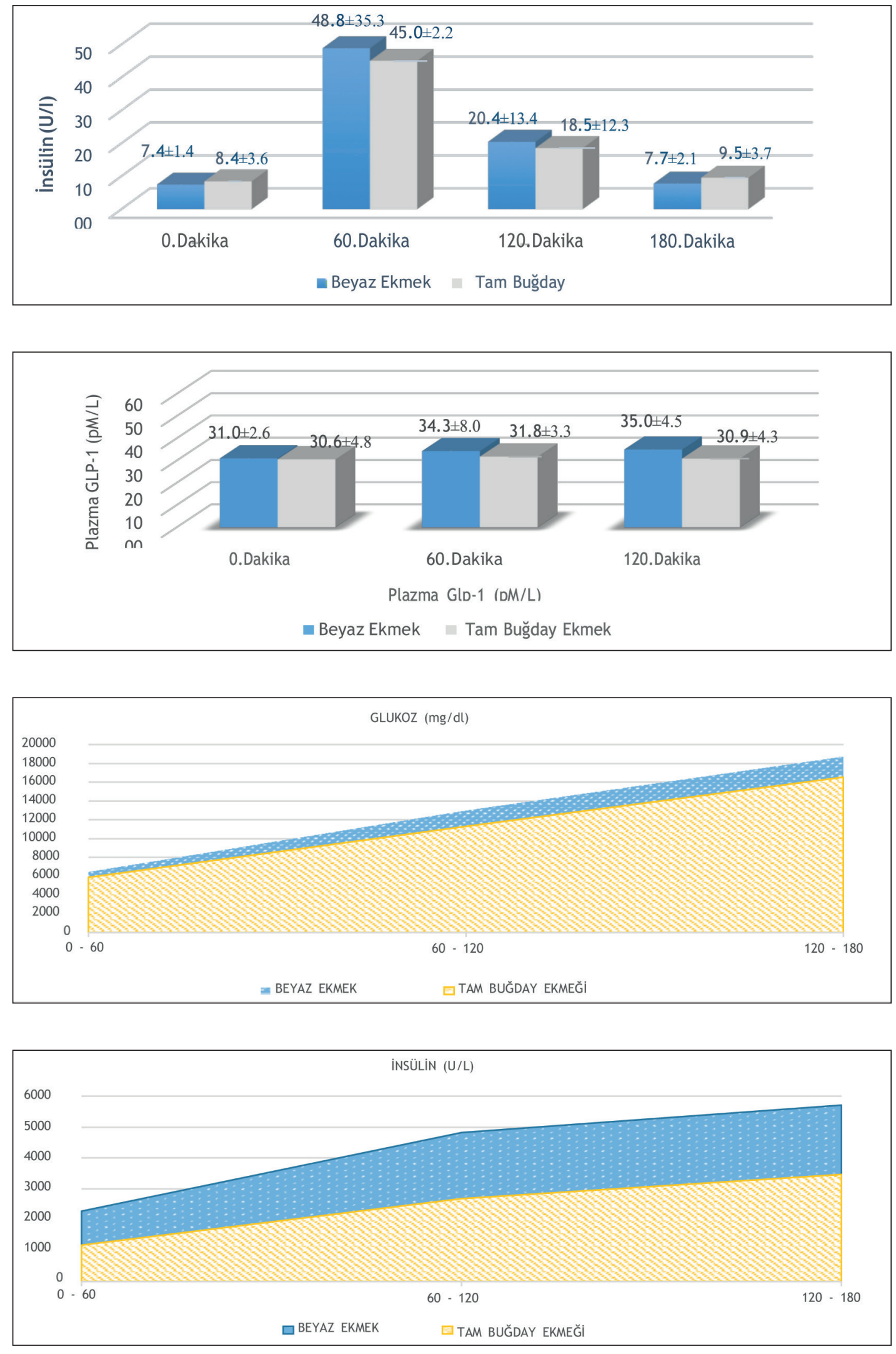

Şekil 11: Kilolu bireylerde Test ekmeklerinin postprandiyal insülin değişimlerinin AUC değerleri. 
Tablo 7 de gösterildiği gibi Obez bireylerin beyaz ekmek ve tam buğday ekmeğine verdikleri metabolik değişikliklerde glukozun tüm tokluk fazlarında $(\mathrm{p}<0,05)$, insülinin ise 60. dakikada toklukta hızlı cevaplı yükseldiği görülürken $(\mathrm{p}<0,01) ; \quad$ GLP-1 düzeyinde anlamlı değişiklikler saptanmamıştır. Bu durum, obezlerde GLP-1 düzeyi daha yüksek saptanmış olmasına rağmen glukoz homeostazisine etkili olan GLP-1 sekresyonunun glukoza yanitının bozulmuş olduğunu düşündürmektedir. Kilolularda korunmuș olan GLP-1 sekresyon cevabının kilo artıșla birlikte azalıyor olduğu şeklinde yorumlanabilir. Obezlerde glukoz, insülin ve GLP- 1 düzeylerinin başlangıç ve başlangıca göre değişimleri Şekil 13, 14 ve 15 'te; AUC'de Şekil 16, 17 ve 18 'de gösterilmiştir.
Obez bireylerin beyaz ekmek tüketiminin tam buğday ekmeğine göre glukoz ve insulin değişimlerinin AUC'leri anlamlı $(\mathrm{p}<0,05)$; GLP-1 değişimi AUC ise anlamlı olmayarak yükseklik gösterdi.

\section{TARTIŞMA}

Ekmek, dünyada en yaygın kullanılan karbonhidrat kaynağıdır (21). Piyasadaki en yaygın ve ticari olarak kullanılan ekmek türü beyaz ekmektir; beyaz ekmek tam tahıllı ekmek ile karşılaştırıldığında daha az diyet lifi içerir ve beyaz ekmeğin, bütün tahıl ekmeği ile karşılaştırıldığında kan șekeri ve insülin düzeylerinde daha sert yükseliș ve düșüșe neden olduğu varsayılır. Bu nedenle, kilo kaybı sağlamaya yönelik diyetler, beyaz ekmeği; çavdar ekmeği, buğday ekmeği ve kepekli ekmek ile değiștirerek oluşturulur (28).
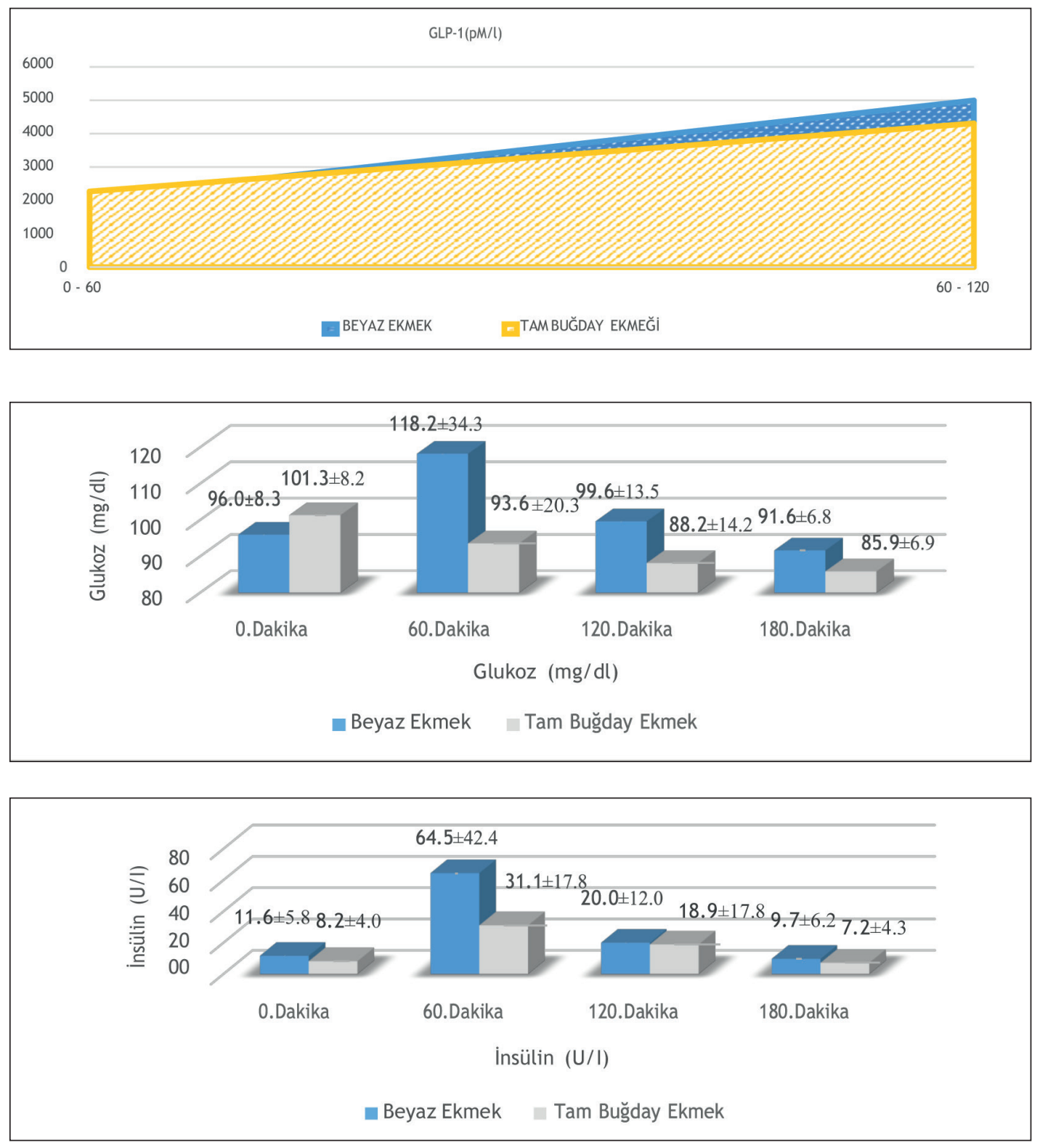

Sekil 12: Kilolu bireylerde Test ekmeklerinin postprandiyal GLP-1 değişimlerinin AUC değerleri.
Şekil 13: Obez bireylerde beyaz ekmek ve tam buğday ekmek testlerinin açlık ve postprandiyal glukoz yanitları.
Şekil 14: Obez bireylerde beyaz ekmek ve tam buğday ekmek testlerinin açlik ve postprandiyal insülin yanitları. 

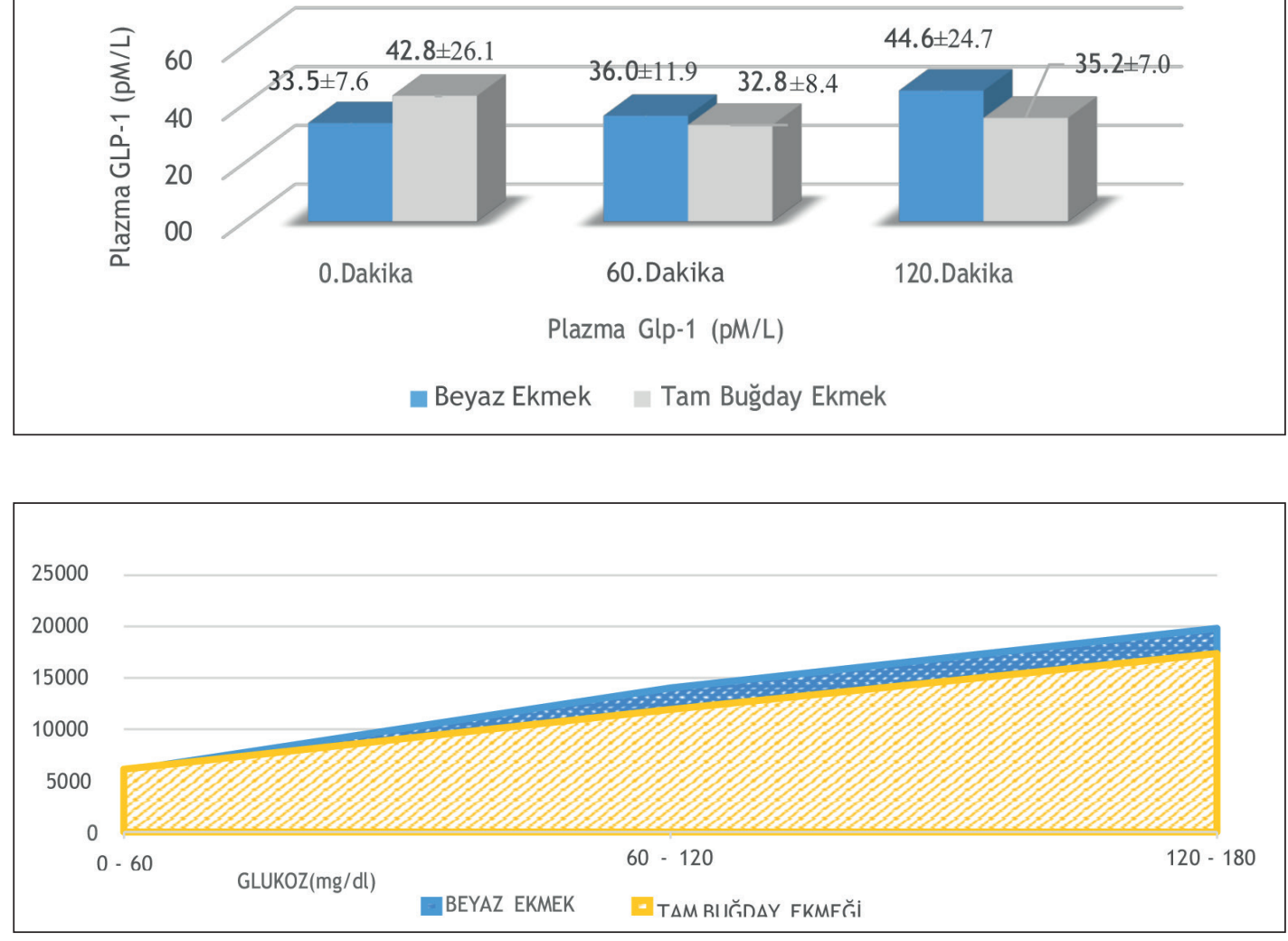

Şekil 16: Obez bireylerde Test ekmeklerinin postprandiyal glukoz değişimlerinin AUC değerleri.

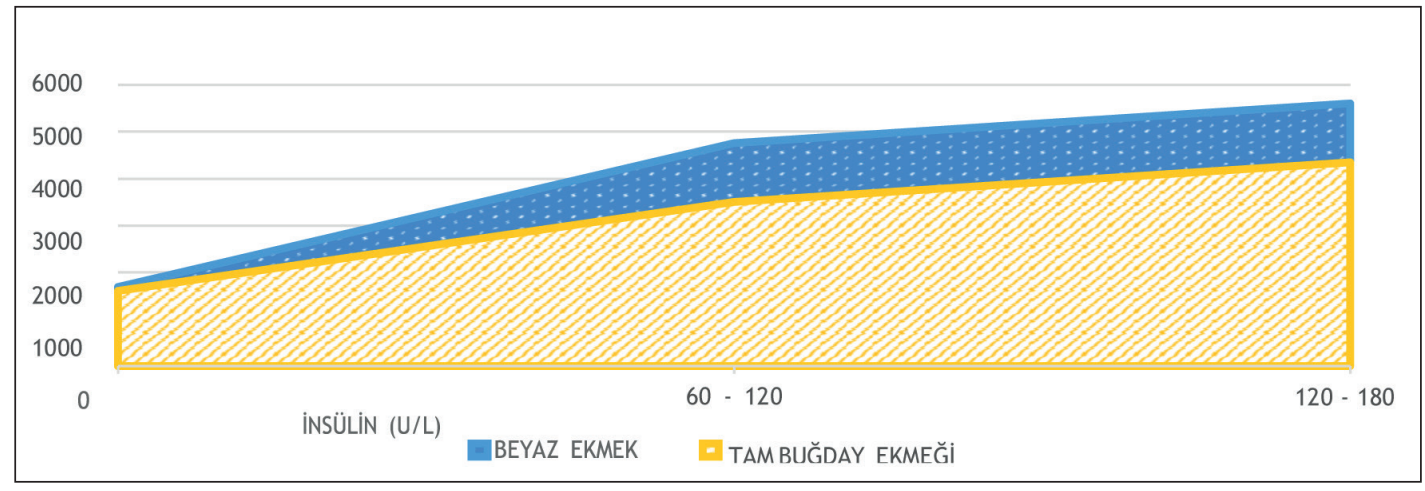

Şekil 17: Obez bireylerde Test ekmeklerinin postprandiyal insülin değişimlerinin AUC değerleri.

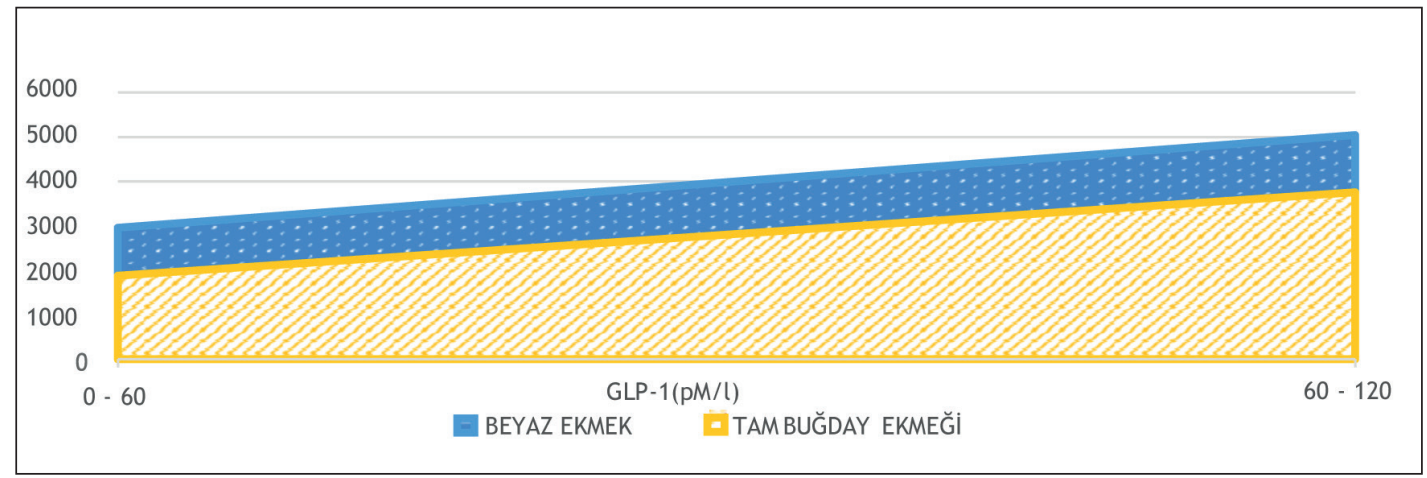

Şekil 18: Obez bireylerde Test ekmeklerinin postprandiyal GLP-1 değişimlerinin AUC değerleri. 
Tokluk parametreleri üzerinde çeşitli ekmek türlerinin akut ve kronik etkileri araştırılmıştır. Çalışmalar çekirdekli çavdar ekmeği, mayalı ekmek ve tam tahıllı ekmeklerin olumlu özellikleri üzerinde durmaktadır (29-33).

Juntunen ve ark.nın 2002` de yaptıkları bir çalışmada, sağlıklı bireylerde beyaz ekmek, çavdar ekmeği, çekirdekli çavdar ekmeği, buğday makarna ve $\beta$-glukan eklenmiş çavdar ekmeğinin açlıkve postprandiyal etkileri çalışmamıza benzer protokolle incelenmiş; $\beta$ - glukan içeren çavdar ekmeğinin postprandiyal glukoz, insülin ve inkretin yanitları (GLP1 ve GIP) diğer ekmeklere göre daha düşük bulunmuştur. Bunda $\beta$-glukan içeren çavdar ekmeğinin diğer ekmeklere göre daha yüksek oranda çözünür lif içermesi etken olarak gösterilmiştir (1).

Modifi ve ark. farklı ekmek çeşitlerinin (beyaz ekmek, çavdar ekmeği, tam buğday ekmeği, kepekli ekmek, mayalı ekmek, tam tahıllı ekmek ve filizlenmiş tahıllı ekmek gibi) metabolik yanıtları ile ilgili çalışmalarında; beyaz ekmek, kepekli ekmek, çavdar ekmeği ve tam tahıllı ekmeğin 2 saatlik tokluk etkilerini karşılaştırılmış; ekmek türlerinin farklı glisemik etkilerini göstermişlerdir. Çavdar ekmeği ve buğday ekmeğinin tokluk kan şekeri yanıtı ve gastrik boşalma hızında fark bulunamazken; özellikle çavdar ekmeği, diğer tip ekmeklere göre daha düşük postabsorptif ve postprandiyal insülin yanıtı verdiğini göstermişlerdir. $\mathrm{Bu}$ durum lif miktarı ve farklı emilim hızları ile açılanabilir (21).

Ekmekte kullanılan unların çeşitleri ve pişirme yöntemlerinin farklılıkları gastrik boşalma hızını etkilediği gibi metabolik yanıtları da etkileyebilir. Bir çalışmada buğday ununu posadan daha zengin arpa unuyla değiştirerek üretilen ekmeklerde insülin cevabı ve kan glukoz düzeyinin daha düşük olduğu görülmüştür (34).

Ekmeğin oluşturduğu metabolik yanıtını düşürmek için diğer bir strateji de ekmeğe, maya (fermentasyonlu) ya da organik asitlerin doğrudan eklenmesidir. Organik asitler, mide boşalma hızını uzatan ve/veya nişasta sindirim oranını azaltan bir mekanizmada yer alır (35-38). Mayalı ekmek tüketiminin tam buğday ekmeğine kıyasla postabsorptif ve postprandiyal dönemde daha düşük glukoz ve GLP-1 yanıtı verdiği görülmüştür. Bu çalışmada mayalı tam tahıllı ekmeklerin olumlu etkilerine dikkat çekilmektedir (37).

Vilsbøll ve ark.nın 2003 te yapmış oldukları çalışmada ekmeğin oluşturduğu inkretin etki araştırılmıştır. Çalışmada katılımcilardan açlık, 30, 40, 50, 60, 90, 100, 120, 130, 140, $150,180,190,210,220,230$ ve 240 . dakika kan örnekleri alınmış; başka bir gün katılımcılara $50 \mathrm{~g}$ beyaz ekmek, $50 \mathrm{~g}$ tam buğday ekmeği, $10 \mathrm{~g}$ tereyağı, $40 \mathrm{~g}$ peynir, $20 \mathrm{~g}$ reçel, 200 ml sütten oluşan (\%34 yağ, \%47 karbonhidrat, \%19 protein),
566 kcallik bir ögün olarak 15 dak içerisinde tükettirilmiştir. İnsülinin açlığa göre postabsorptif dönemde pik yaptığ 1 gözlenmiştir. $\mathrm{C}$ peptid değerleri de insulin benzeri sonuç vermiştir. Çalışmada GIP ve GLP- 1'in hemen hemen birbirine eş değer bir inkretin etki göstererek, plazma glukoz düzeylerini etkilediği sonucuna varılmıştır. (38).

Yapılan çalışmalarda, zayıf kişilerde karbonhidrat tüketiminden sonra GLP-1 salınımının, obez bireylerdekinden daha yüksek miktarda olduğu, yağ tüketiminden sonra ise zayıf ve obezler arasında fark bulunmadığ 1 gösterilmiștir (13). Aksini gösteren bașka bir çalışmada da aşırı kilolu ve kilolu bireylerde, fizyolojik olarak GLP-1 düzeyleri yüksek olduğu; bunun da negatif enerji dengesini sağladığı gösterilmiştir. (39). Çalışmamızda bu çalışmayı destekler yöndeydi. Obez grubun test öncesi ve sonrasındaki tüm tokluk saatlerinde GLP-1 düzeylerinin, kilolu gruptan daha yüksek olduğu gözlenmiştir.

Obez bireylerin test ekmeklerini tüketimleri değerlendirildiğinde beyaz ekmek sonrası glukoz, insülin ve GLP-1 değerlerinin tam buğday ekmekle yapılana göre daha yüksek seviyelerde olduğu gözlemlendi. Bu gözlem, obez katılımcılar için bozulmuş GLP-1 yanıtı olarak değerlendirilebilirken; kilolu katılımcılar açısından GLP-1 cevabının korunabildiği şeklinde yorumlanabilir.

Kilolu bireyler obez bireylere göre tam buğday ekmeği tüketiminde insülin düzeyinde anlamlı olmayan ve daha az, GLP-1 düzeyinde postprandiyal dönemde daha fazla yükselme göstermiştir. Genel olarak tam buğday ekmeğinin kilolu bireylerde beyaz ekmeğe göre daha olumlu bir etki gösterdiği söylenebilir.

Çalışma ilk hafta tam buğday ekmeği ile yapıldı; sonraki hafta beyaz ekmek ile devam ettirildi. Bireylerin tam buğday ekmeği tükettikleri ilk hafta açlık glukoz değerleri yüksekti. Buna rağmen tam buğday ekmeği tüketimiyle kan şekeri değişimleri beyaz ekmek tüketimine göre daha az yükselme göstermiştir. Beyaz ekmekle glukoz değişimi anlamlı yükselme gösterdi $(p<0,05)$.

Çalışmada genel olarak beyaz ekmek tüketen $\mathrm{KH}$ intoleransı olmayan obez ve kilolu katılımcılarda tam buğday ekmeğine göre glukoz cevabının her dönemde daha fazla, insülin cevabının postabsortif dönemde ve GLP-1 düzeyinin de postprandiyal dönemde daha fazla olduğu söylenebilir. İnsülin cevabının yüksek olması beyaz ekmek tüketiminden sonraki hızlı KH emilimi ve GLP-1 salınımı ile ilişkili olarak değerlendirilebilir. Bunun bir sebebi beyaz ekmeğin içerdiği lif içeriğinin tam buğday ekmeğine göre daha düşük olması olarak gösterilebilir. 
Türk toplumu kişi başı ekmek tüketiminde dünyada ilk sıralarda yer almaktadır ve bu ekmeğin \%90'ını beyaz ekmek oluşturmaktadır. Birçok çalışma glukoz ve insülinin metabolik yanıtlarında beyaz ekmeğin olumsuz etkilerini göstermektedir. İnsulin en önemli uyarıcı olan GLP-1'nin ve GIP'in rolü de burada önemlidir. Toplum, beyaz ekmek tüketimini azaltmak ve beyaz ekmeği tam tahıl ekmekleri ile değiştirmek yönünde teşvik edilmelidir.

Bu çalışma, obez ve normal sağlıklı ve diyabeti olan gruplarda farkli ekmek çeşitlerinin eklenmesiyle zenginleşebilirdi fakat ekonomik kısıtlılıklar buna olanak sağlayamadı. Yapılacak yeni çalışmalarda karbonhidrat türlerinin çeşitlendirilmesi (mısır ekmeği, lavaş, mayalı ekmek, çavdar ekmeği, erişte, makarna, tarhana... gibi) ve karbonhidrat intoleransı olan obez ve normal kilo aralığındaki bireylerde testlerin yapılması anlamlı sonuçlar getirebilir.

\section{KAYNAKLAR}

1. Juntunen KS, Niskanen LK, Liukkonen KH, Poutanen KS, Holst JJ, Mykkanen HM. Postprandial glucose, insulin, and inkretin responses to grain producuts in healthy subjects. Am J Clin Nutr 2002;75:254-262.

2. Türkiye Beslenme ve Sağlik Araştirması (TBSA) 2010. Erişim tarihi: 29.09.2014. http://ekutuphane.sagem.gov.tr/.

3. Newby PK, Maras J, Bakun P, Muller D, Ferruci L, and Tucker LK. Intake of whole grains, refined grains, and cereal fiber measured with 7-d diet records and associations with risk factors for chronic disease. Am J Clin Nutr 2007;86:1745-1753.

4. Pereira MA, Jacobs DR, Pins JJ, et al. Effect of whole grains on insulin sensivity in overweight hyperinsulinemich adults. Am J Clin Nutr 2002;75:848-855.

5. Jensen KM, Koh-Banerjee P, Franz M, Sampson L, Grønbak $\mathrm{M}$, Rimm BE. Whole grains, bran, and germ in relation to homocysteine and markers of glycemic control, lipids, and inflammation. Am J Clin Nutr 2006;83:275-283.

6. Flight I, Clifton P. Cereal grains and legumes in the prevention of coronary heart disease and stroke: A review of the literature. Eur J Clin Nutr 2006;60:1145-1159.

7. Sciacqua A, Perticone M, Falbo T, Grillo N, Tassone EJ, Sinopoli F, Lo Russo C, Succurro E, Andreozzi F, Sesti G, Perticone F. Dietary patterns and 1-h post-load glucose in essential hypertension. Nutr Metab Cardiovasc Dis 2013;13:4739-4753.

8. Pericleous M, Mandair D, Caplin EM. Diet and supplements and their impact on colorectal cancer. J Gastrointest Oncol 2013;4:409-423.

9. Yao B, Fang H, Xu W, Yan Y, Xu H, Liu Y, Mo M, Zhang $\mathrm{H}$, Zhao Y. Dietary fiber intake and risk of type 2 diabetes: A dose-response analysis of prospective studies. Eur J Epidemiol 2014;10:10654-10013.

10. Ramage S, Farmer A, Eccles KA and McCargar L. Healthy strategies for successful weight loss and weight maintenance: A systematic review. Appl Physiol Nutr Metab 2014;39:1-20.
11. Kamp, Van Der JW. Dietary fibre: New frontiers for food and health. Wageningen Academic Publishers, 2010:586.

12. Bonora E, Muggeo M. Postprandial blood glucose as a risk factor for cardiovascular disease in Type II diabetes: The epidemiological evidence. Diabetologia 2001;44:2107-2114.

13. Burcelin R. The incretins: A link between nutrients and wellbeing. Br J Nutr 2005;93:147-156.

14. Cernea S, Dobreanu M. Diabetes and beta cell function: From mechanisms to evaluation and clinical implications. Biochem Med 2013;23:266-280.

15. Vilsbøll T. The effects of glucagon-like peptide-1 on the beta cell. Diabetes Obes Metab 2009;11 Suppl 3:11-18.

16. Holst J. The Physiology of glucagon-like peptide 1. Physiol Rev 2007;87:1409-1439.

17. Nauck MA. Unraveling the science of incretin biology. Eur J Intern Med 2009;20:303-308.

18. Geelhoed-Duijvestijn PM. Incretins: New treatment potion for type 2 diabetes. Neth J Med 2007;65:60-64.

19. Girard J. The incretins: From the concept to their use in the treatment of type 2 diabetes. Diabetes Metab 2008;34:550-559.

20. Axelsen M, Arvidsson LR, Lonnroth P, Smith U. Breakfast glycaemic response in patients with type 2 diabetes: Effects of bedtime dietary carbonhyrates. Eur J Clin Nutr 1999;53:706710 .

21. Mofidi A, Ferraro ZM, Stewart KA, Tulk HMF, Robinson LE, Duncan AM, Graham TE. The Acute impact of ingestion of sourdough and whole-grain breads on blood glucose, insulin and incretins in overweight and obese men. J Nutr Metab 2012;2012:184710.

22. Penaforte FRO, Japur CC, Diez-Garcia RW, Chiarello PG. Effects of a high-fat meal on postprandial incretin responses, appetite scores and ad libitum energy intake in women with obesity. Nutr Hosp 2017;34(2):376-382.

23. Ranganath LR. The entero-insular axis: Implications for human metabolism. Clin Chem Lab Med 2008;46(1):43-56.

24. Drucker D. The role of gut hormones in glukoce homeostasis. J Clin Invest 2007;117(1):24-32.

25. Brubaker PL. Minireview: Update on incretin biology: Focus on glucagon like peptide-1. Endocrinology 2010;151:19841989.

26. Brubaker PL, Gil-Lozano M. Glucagon-like peptide-1: The missing link in the metabolic clock? J Diabetes Investig 2016; 1:70-75.

27. Eelderink C, Noort MW, Sozer N, Koehorst M, Holst JJ, Deacon CF, Rehfeld JF, et al. Difference in postprandial GLP1 response despite similar glucose kinetics after consumption of wheat breads with different particle size in healthy men. Eur J Nutr 2017;56:1063-1076.

28. Najjar MA, Parsons PM, Duncan MA, Robinson EL, Yada YR, Graham TE. The acute impact of ingestion of breads of varying composition on blood glucose, insulin and incretins following first and second meals. Br J Nutr 2009;101:391-398. 
29. Zammit, VA, Waterman, IJ, Topping D, McKay, G. Insulin stimulation of hepatic triacylglycerol secretion and the etiology of insulin resistance. J Nutr 2001;131(8):2074-2077.

30. Mesci B, Kılıç D, Oguz A. Dietary breads and impact on postprandial parameters. Flour and Breads and their Fortification in Health and Disease Prevention 2011; 429-435.

31. Tucker AJ, Vandermey JS, Robinson LE, Graham TE, Bakovic M, Duncan AM. Effects of breads of varying carbohydrate quality on postprandial glycaemic, incretin and lipidaemic response after first and second meals in adults with dietcontrolled type 2 diabetes. Journal of Functional Foods 2014; 6: 116-125.

32. Bo S, Seletto M, Choc A, Ponzo V, Lezo A, Demagistris A, Evangelista A, Ciccone G, Bertolino M, et al. The acute impact of the intake of four types of bread on satiety and blood concentrations of glucose, insulin, free fatty acids, triglyceride and acylated ghrelin. A randomized controlled cross-over trial. Food Res Int 2017; 92: 40-47.

33. Nounmusig J, Kongkachuichai R, Sirichakwal PP, Yamborisut $\mathrm{U}$, Charoensiri R, Vanavichit A. The effect of low and high glycemic index based rice varieties in test meals on postprandial blood glucose, insulin and incretin hormones response in prediabetic subjects. International Food Research Journal 2018;25: 835-841.
34. Liljeberg H, Bjorck I. Delayed gastric emptying rate may explain improved glycaemia in healthy subjects to a starchy meal with added vinegar. Eur J Clin Nutr 1998;52:368-371.

35. Liljeberg HG, Lonner CH, Bjorck IM. Sourdough fermentation or addition of organic acids or corresponding salts to bread improves nutritional properties of starch in healthy humans. J Nutr 1995;125:1503-1511.

36. Liljeberg HG, Bjorck IM. Delayed gastric emptying rate as a potential mechanism for lowered glycemia after eating sourdough bread: Studies in humans and rats using test products with added organic acids or an organic salt. Am J Clin Nutr 1996;64:886-893.

37. Ostman EM, Liljeberg Elmstahl HG, Bjorck, IM. Barley bread containing lactic acid improves glucose tolerance at a subsequent meal in healthy men and women. J Nutr 2002;132:1173-1175.

38. Vilsbøll T, Krarupa T, Madsbadc S, Holst J. Both GLP-1 and GIP are insulinotropic at basal and postprandial glucose levels and contribute nearly equally to the incretin effect of a meal in healthy subjects. Regul Pept 2003;114:115-121.

39. Adam TC, Jocken J, Westerterp-Plantenga MS. Decreased glucagon-like peptide 1 release after weight loss in overweight/ obese subjects. Obes Res 2005;13:710-716. 
